\title{
Communication
}

\section{Understanding the Causality between Carbon Dioxide Emission, Fossil Energy Consumption and Economic Growth in Developed Countries: An Empirical Study}

\section{Bing Xue ${ }^{1, *}$, Yong Geng ${ }^{1, \dagger}$, Katrin Müller ${ }^{2, \dagger}$, Chengpeng Lu ${ }^{1, \dagger}$ and Wanxia Ren ${ }^{1, \dagger}$}

1 Key Laboratory of Pollution Ecology and Environmental Engineering, Institute of Applied Ecology, Chinese Academy of Sciences, Shenyang 110016, China; E-Mails: gengyong@iae.ac.cn (Y.G.); luchp.lzu@gmail.com (C.L.); renwanxia@iae.ac.cn(W.R.)

2 Institute for Applied Material Flow Management, University of Applied Sciences Trier, Birkenfeld D-55768, Germany; E-Mail: katrin.mueller@student. unisg.ch

$\dagger$ These authors contributed equally to this work.

* Author to whom correspondence should be addressed; E-Mail: xuebing@iae.ac.cn; Tel.: +86-24-8397-0433; Fax: +86-24-8397-0371.

Received: 30 January 2014; in revised form: 12 February 2014 / Accepted: 13 February 2014 / Published: 21 February 2014

\begin{abstract}
Issues on climate change have been recognized as serious challenges for regional sustainable development both at a global and local level. Given the background that most of the artificial carbon emissions are resulted from the energy consumption sector and the energy is also the key element resource for economic development, this paper investigated the relationship between $\mathrm{CO}_{2}$ emission, fossil energy consumption, and economic growth in the period 1970-2008 of nine European countries, based on the approach of Granger Causality Test, followed by the risk analysis on impacts of $\mathrm{CO}_{2}$ reduction to local economic growth classified by the indicator of causality degree. The results show that there are various feedback causal relationships between carbon emission, energy consumption and economic growth, with both unidirectional and dual-directional Granger causality. The impact of reducing $\mathrm{CO}_{2}$ emission to economic growth varies between countries as well.
\end{abstract}

Keywords: climate change; carbon reduction; regional disparity; causality test; European countries 


\section{Introduction}

Global climate change has been a hot topic since the end of the 20th century (see, for instance, [1-3]), and it is currently also a major concern and challenge confronting countries in the world [4], for example, the report of IPCC4 pointed that it was very likely (more than $90 \%$ of probability) that global warming was related to the increasing of greenhouse gases (GHG) over the past 50 years [5]. Concerning climate change mitigation and adaption, the Kyoto Protocol is a very important step for reducing GHG emissions, and, moreover, broader participation and deeper cuts in GHG emissions are essential for any post-Kyoto agreement [6]. However, the common recognition on reducing GHG emissions from the past several Conferences of Parties (COP) to the United Nations Framework Convention on Climate Change, such as the COP 15 in 2009 of Copenhagen, COP 17 in 2011 of Duban and COP19 in 2013 of Warsaw are not sufficient enough. The key issue for reaching a consensus on GHG emission reduction is the concern on its impact to local economic development [7], either in developed regions or in developing and emerging countries. For example, van Renssen explored the worries voiced within industry and argued that Europe must come up with effective climate, environment and energy policies that do not jeopardize economic competitiveness [8], Wang et al. [9] stated that China's economic growth and export trade had significantly promoted its carbon emissions, and the rapid economic growth is the main determinant that causes an increase in carbon emissions [10]. Major emitters seem unwilling to accept binding emissions reductions targets as their economies have stagnated [11]. Given the common background that most of the artificial carbon emission results from the energy consumption sector and that energy is also the key element resource for economic development [12], the causal relationship between carbon emission, energy consumption and economic growth should be investigated. This could offer better understanding on the interaction impacts to local sustainable development [13-15].

As for developing and emerging countries, such as China, India and Brazil, the question as to how to delink the energy consumption and carbon emission from the economic growth has been the key issue faced by policy makers and scientific communities. However, currently, in the face of international pressure to curb carbon releases as well as the tight domestic fossil-energy supply [16], relative indicators are usually applied for measuring carbon reduction target in order to avoid the possible negative impacts on local economic development [17]. For example, a case study for Brazil shows that the business-as-usual $\mathrm{CO}_{2}$ emissions in 2040 from energy use and industrial processes would be almost three times as high as those in 2010, while the current policy aims to lower emissions intensity of the overall economy by 36-39 percent by 2020 [18]. Another analysis on carbon reduction in China indicates that the region with a lower reduction benchmark and higher decoupling elasticity value has more difficulty in achieving the emission reduction targets without powerful relevant policy [19], and a provincial level case study illustrates that with the rapid economic development, $\mathrm{CO}_{2}$ emission in Jiangsu province rose from $1,88 \times 10^{8} \mathrm{t}$ in 1995 to $5,20 \times 10^{4} \mathrm{t}$ in 2009 , with an average annual growth rate of $7.54 \%$ [20]. Even the Chinese central government has stated that in 2020 the carbon intensity will be reduced by $40 \%-45 \%$ compared to the 2005 level [21]. An early study that aimed to examine the long-run relationship between output and energy consumption during the period 1971-1999 in Malaysia indicated that energy use was positively related to output in the long-run, and offered strong support for causalities running from economic growth to energy consumption growth 
both in the short-run and long-run [22]. Research in the case of South Africa on the effects of economic growth and coal consumption on $\mathrm{CO}_{2}$ emissions over the period 1965-2008 also shows that a rise in economic growth increases energy emissions, and coal consumption makes a significant contribution to deteriorating the environment [23], which was also verified by Menyah and Wolde-Rufael's research [24]. Under such circumstances, investigation and insights into the relationship between carbon emission, energy consumption and economic growth in developed countries could offer further understanding for developing countries.

As the typical representatives of developed and industrialized countries in this world, Europe plays a leading role in climate change mitigation and adaptation. Thus, investigating the causal relationship between the mentioned elements is significant and could have policy implications for developing countries. Actually, few related studies have been done: Ang investigated the dynamic causal relationships between pollutant emissions, energy consumption, and output for France by using co-integration and vector error-correction modeling techniques for the period 1960-2000, and the causality results support the argument that economic growth exerts a causal influence on growth of energy use and growth of pollution in the long run [25]. Marrero took the advantage of a panel data set of 24 European countries in the period of 1990-2006 and applied a Dynamic Panel Data framework to examine the relationship of GHG emissions, growth and the energy mix in Europe, and found evidence for the existence of conditional convergence in terms of GHG emissions among the EU27 countries [26]. The change in energy intensity of the main economic activities in period of 1991-2005 of the EU15 countries was also investigated by Marrero and Ramos-Real in 2013, and the results revealed four different typologies for EU15 countries and showed the importance of identifying those economic activities which are key to reducing energy consumption [27].

Herein, based on the statistical data in the open database of World Bank, nine European countries, namely, Denmark, France, Greece, Italy, Netherlands, Portugal, Spain, Sweden and United Kingdom are selected to investigate the causal relationship between GDP growth, energy consumption and $\mathrm{CO}_{2}$ emissions in the period of 1970-2008, and followed by the evaluation on the possible impacts of $\mathrm{CO}_{2}$ emissions reduction to economic development by ranking the classes based on the causality degree results.

\section{Methodologies and Results}

Selected variables used in this study include: (1) GDP per capita (GDPP) which represents the local economic developmental level of studied countries, (2) $\mathrm{CO}_{2}$ emissions per capita $\left(\mathrm{PCO}_{2}\right)$ which represents the contribution of economic activities to climate change, and (3) Energy Consumption Intensity (ECI) (fossil energy consumption per capita) which represents the fossil energy resources consumption affected by the type of the fossil energy mix and population.

\subsection{Unit Root Test}

Co-integration analysis introduces the idea that even if underlying time series are non-stationary, linear combinations of these series might be stationary. Therefore it is essential to verify that all variables are integrated of order one in levels before employing panel co-integration techniques. The main idea behind performing a unit root test while using ADF statistics is to ensure that the error term should be 
lagged independent [14]. In this method, the unit root test is carried out by means of the following formulation [15].

$$
\Delta Y_{t}=\alpha+\rho Y_{t-I}+8 T+\sum b_{i} \Delta Y_{t-1}+\varepsilon_{t}, i=1,2, \ldots, \mathrm{n}
$$

Together with the fixed term regressions with trend, ADF statistics and McKinnon's critical values are derived. Where $\Delta \mathrm{Y}_{t}=Y_{t}-Y_{t-i}, \alpha$ is a drift term, and $\mathrm{T}$ is the time trend with the null hypothesis $H_{0}: \rho=0$ and $H_{1}$ its alternative hypothesis $H_{1}: \rho \neq 0, n$ is the number of lags necessary to obtain white noise, and $\varepsilon$ is the error term. Failure in rejecting $H_{0}$ implies that the time series is non-stationary. The unit root tests of all the three variables sets mentioned above for the nine countries are tested under differential levels of both first/second differences. From Table 1, we could conclude that most of the unit root hypothesizes have not been rejected when the variables are taken in various levels, but when the first difference was used, most of the hypothesizes of unit root non-stationary are rejected at the level $1 \%$ or level $5 \%$ of the significance, and few of the hypothesizes of unit root non-stationary are rejected under the second differences at level $1 \%$.

Table 1. Results of the unit root test in first difference.

\begin{tabular}{|c|c|c|c|c|}
\hline Countries & Variables' series & t-Statistic & Probability & $1 \%$ level \\
\hline \multirow{3}{*}{ France } & $\mathrm{PCO}_{2}$ & -7.1534 & 0.0000 & -3.6267 \\
\hline & ECI & -6.8673 & 0.0000 & -3.6267 \\
\hline & GDPP & -4.0121 & 0.0037 & -3.6267 \\
\hline \multirow{3}{*}{ United Kingdom } & $\mathrm{PCO}_{2}$ & -7.3724 & 0.0000 & -3.6267 \\
\hline & ECI & -6.2971 & 0.0000 & -3.6267 \\
\hline & GDPP & -4.5310 & 0.0009 & -3.6267 \\
\hline \multirow{3}{*}{ Italy } & $\mathrm{PCO}_{2}$ & -6.0026 & 0.0000 & -3.6267 \\
\hline & ECI & -5.9801 & 0.0000 & -3.6267 \\
\hline & GDPP & -4.2535 & 0.0019 & -3.6267 \\
\hline \multirow{3}{*}{ Spain } & $\mathrm{PCO}_{2}$ & -5.1532 & 0.0002 & -3.6267 \\
\hline & ECI & -4.2121 & 0.0021 & -3.6267 \\
\hline & GDPP & -3.3031 & 0.0221 & $-2.9458^{\mathrm{a}}$ \\
\hline \multirow{3}{*}{ Sweden } & $\mathrm{PCO}_{2}$ & -7.5831 & 0.0000 & -3.6267 \\
\hline & ECI & -6.7491 & 0.0000 & -3.6267 \\
\hline & GDPP & -4.3146 & 0.0016 & -3.6267 \\
\hline \multirow{3}{*}{ Portugal } & $\mathrm{PCO}_{2}$ & $-10.130^{b}$ & 0.0000 & -3.6394 \\
\hline & ECI & -5.7287 & 0.0000 & -3.6267 \\
\hline & GDPP & -3.8520 & 0.0056 & -3.6267 \\
\hline \multirow{3}{*}{ Netherlands } & $\mathrm{PCO}_{2}$ & -6.0089 & 0.0000 & -3.6267 \\
\hline & ECI & $-2.9170^{\mathrm{c}}$ & 0.0530 & -3.6210 \\
\hline & GDPP & -3.4434 & 0.0158 & -3.6267 \\
\hline \multirow{3}{*}{ Greece } & $\mathrm{PCO}_{2}$ & -6.8068 & 0.0000 & -3.6267 \\
\hline & ECI & -5.7685 & 0.0000 & -3.6267 \\
\hline & GDPP & $-5.4214^{b}$ & 0.0001 & -3.6463 \\
\hline \multirow{3}{*}{ Denmark } & $\mathrm{PCO}_{2}$ & $-2.6389^{c}$ & 0.0945 & -3.6210 \\
\hline & ECI & -3.4166 & 0.0166 & -3.6210 \\
\hline & GDPP & -3.7237 & 0.0078 & -3.6268 \\
\hline
\end{tabular}

${ }^{\mathrm{a}}$ at level $5 \% ;{ }^{\mathrm{b}}$ tested in level $10 \% ;{ }^{\mathrm{c}}$ tested in 2 nd difference. 


\subsection{Co-Integration Test}

The co-integration test was employed in order to determine whether there exists a co-integration between the studied series. The aim of co-integration analysis is to model and estimate the long term correlation-ship among non-stationary time series. Herein, the Johansen co-integration procedure was performed for determining whether the co-integration exists. The first step in Johansen procedure is to determine the lag order. In this study, the significant and right lag period is finally selected after the numbers test from lag 1 to lag 10 and followed by the trace statistic and the maximum Eigen-value statistic (see the supplementary materials). The result shows that causality exists among the selected variables series; however, the co-integration test cannot tell the direction of the causal relationship. Thus, the following multivariate Granger-causality test based on the VECM was carried out to investigate both short-run and long-run causality.

\subsection{Granger Causality}

If the series $X$ and $Y$ are individually $I(1)$ and co-integrated as well, then the Granger causality tests could use $I(1)$ data because of the super consistency properties of estimation, whereas $u_{t}$ and $v_{t}$ are zero-mean, serially uncorrelated, random disturbances. The optimum lag lengths $m, n, q$ and $r$ are determined on the basis of Schwarz Bayesian and/or log-likelihood ratio test criterion:

$$
X_{\mathrm{t}}=a_{0}+\sum_{i=1}^{m} a_{1 i} X_{t-i}+\sum_{i=1}^{n} a_{2 i} Y_{t-i}+u_{t}
$$

In the above equation, $Y$ Granger causes $X$ if $H_{0}: \mathrm{a}_{21}=\mathrm{a}_{22}=\ldots \mathrm{a}_{2 \mathrm{n}}=0$ is rejected, and $H 1$ : at least on $\mathrm{a}_{2 \mathrm{i}} \neq 0, I=1,2,3, \ldots, n$. and, correspondingly, in the following equation, $X$ Granger causes $Y$ if $H_{0}$ : $\mathrm{b}_{21}=\mathrm{b}_{22}=\ldots \mathrm{b}_{2 \mathrm{n}}=0$ is rejected, and $H_{1}$ : at least on $\mathrm{b}_{2 \mathrm{i}} \neq 0, i=1,2,3, \ldots, \mathrm{r}$ :

$$
\mathrm{Y}_{\mathrm{t}}=b_{0}+\sum_{i=1}^{q} b_{1 i} Y_{t-i}+\sum_{i=1}^{r} b_{2 i} X_{t-i}+v_{t}
$$

Results of the Granger-causality test for the 9 countries show that there are various feedback causal relationships between carbon emission, energy consumption and economic growth, with both unidirectional and dual-directional causalities (Table 2, and supplementary materials). In conclusion, (1) Granger Causality between energy consumption and $\mathrm{CO}_{2}$ emissions: the null hypothesis of "ECI does not Granger Cause $\mathrm{PCO}_{2}$ " and " $\mathrm{PCO}_{2}$ does not Granger Cause ECI" are rejected in countries of France, Spain and Sweden, but accepted in countries of United Kingdom, Italy, Portugal and Greece; while in Denmark, the null hypothesis of "ECI does not Granger Cause $\mathrm{PCO}_{2}$ " is rejected but that of " $\mathrm{PCO}_{2}$ does not Granger Cause ECI" is accepted; (2) Granger Causality between economic growth and $\mathrm{CO}_{2}$ emissions, the null hypothesis of "GDPP does not Granger Cause $\mathrm{PCO}_{2}$ " and " $\mathrm{PCO}_{2}$ does not Granger Cause GDPP” are all accepted for most of the countries includes France, Italy, Spain, Sweden, Portugal, Netherlands and Greece; while for United Kingdom, the null hypothesis of "GDPP does not Granger Cause $\mathrm{PCO}_{2}$ " is rejected but that of " $\mathrm{PCO}_{2}$ does not Granger Cause GDPP" is accepted; however, the situation in Denmark is opposite than that in the United Kingdom.

Comparing the differences based on the long term, conclusions are summarized as follows: (1) for France, Spain and Sweden, the causality relationship between ECI and $\mathrm{PCO}_{2}$ is reciprocal relation, 
but has no causality relationship between GDPP and $\mathrm{PCO}_{2}$; (2) for the United Kingdom, there exist non-causality relationship between ECI and $\mathrm{PCO}_{2}$, and GDPP is the Granger causality to $\mathrm{PCO}_{2}$ while $\mathrm{PCO}_{2}$ is not the Granger causality to GDPP; (3) for Italy, Portugal and Greece, there no causality exists between ECI and $\mathrm{PCO}_{2}$, and between GDPP and $\mathrm{PCO}_{2}$. (4) for the Netherlands, ECI is not the Granger Cause to $\mathrm{PCO}_{2}$, but $\mathrm{PCO}_{2}$ is the granger cause to ECI; in addition, there exists a non-causality relationship between GDPP and $\mathrm{PCO}_{2}$; (5) for Denmark, ECI is the Granger Cause to $\mathrm{PCO}_{2}$, but $\mathrm{PCO}_{2}$ is not the granger cause to ECI; also the same situation exists between GDPP and $\mathrm{PCO}_{2}$.

Table 2. Granger-causality test results for nine countries from 1970-2008.

\begin{tabular}{|c|c|c|c|c|c|c|}
\hline Countries & Null Hypothesis & Obs & Lag & F-Statistic & Probability & Result (1\%) \\
\hline \multirow{4}{*}{ France } & ECI does not Granger Cause $\mathrm{PCO}_{2}$ & \multirow{2}{*}{33} & \multirow{2}{*}{5} & 6.65201 & 0.00065 & Reject \\
\hline & $\mathrm{PCO}_{2}$ does not Granger Cause ECI & & & 2.82848 & 0.04043 & Reject \\
\hline & GDPP does not Granger Cause $\mathrm{CO}_{2}$ & \multirow{2}{*}{33} & \multirow{2}{*}{5} & 0.92345 & 0.48451 & Accept \\
\hline & $\mathrm{CO}_{2}$ does not Granger Cause GDPP & & & 0.52934 & 0.75166 & Accept \\
\hline \multirow{4}{*}{ United Kingdom } & ECI does not Granger Cause $\mathrm{PCO}_{2}$ & \multirow{2}{*}{37} & \multirow{2}{*}{1} & 2.82977 & 0.10170 & Accept \\
\hline & $\mathrm{PCO}_{2}$ does not Granger Cause ECI & & & 0.01032 & 0.91968 & Accept \\
\hline & GDPP does not Granger Cause $\mathrm{CO}_{2}$ & \multirow{2}{*}{37} & \multirow{2}{*}{1} & 7.00927 & 0.01220 & Reject \\
\hline & $\mathrm{CO}_{2}$ does not Granger Cause GDPP & & & 0.00292 & 0.95720 & Accept \\
\hline \multirow{4}{*}{ Italy } & ECI does not Granger Cause $\mathrm{PCO}_{2}$ & \multirow{2}{*}{35} & \multirow{2}{*}{3} & 0.91294 & 0.44730 & Accept \\
\hline & $\mathrm{PCO}_{2}$ does not Granger Cause ECI & & & 1.34415 & 0.28009 & Accept \\
\hline & GDPP does not Granger Cause $\mathrm{CO}_{2}$ & & & 0.46991 & 0.70566 & Accept \\
\hline & $\mathrm{CO}_{2}$ does not Granger Cause GDPP & 35 & 3 & 1.29007 & 0.29716 & Accept \\
\hline \multirow{4}{*}{ Spain } & ECI does not Granger Cause $\mathrm{PCO}_{2}$ & \multirow{2}{*}{37} & \multirow{2}{*}{1} & 10.4269 & 0.00275 & Reject \\
\hline & $\mathrm{PCO}_{2}$ does not Granger Cause ECI & & & 13.7206 & 0.00075 & Reject \\
\hline & GDPP does not Granger Cause $\mathrm{CO}_{2}$ & & 1 & 0.00693 & 0.93415 & Accept \\
\hline & $\mathrm{CO}_{2}$ does not Granger Cause GDPP & 31 & 1 & 0.01997 & 0.88845 & Accept \\
\hline \multirow{4}{*}{ Sweden } & ECI does not Granger Cause $\mathrm{PCO}_{2}$ & \multirow{2}{*}{37} & \multirow{2}{*}{1} & 5.16707 & 0.02946 & Reject \\
\hline & $\mathrm{PCO}_{2}$ does not Granger Cause ECI & & & 7.32624 & 0.01055 & Reject \\
\hline & GDPP does not Granger Cause $\mathrm{CO}_{2}$ & \multirow{2}{*}{37} & \multirow{2}{*}{1} & 2.80925 & 0.10290 & Accept \\
\hline & $\mathrm{CO}_{2}$ does not Granger Cause GDPP & & & $8.4 \times 10^{-7}$ & 0.99928 & Accept \\
\hline \multirow{4}{*}{ Portugal } & ECI does not Granger Cause $\mathrm{PCO}_{2}$ & \multirow{2}{*}{33} & \multirow{2}{*}{5} & 2.05856 & 0.10960 & Accept \\
\hline & $\mathrm{PCO}_{2}$ does not Granger Cause ECI & & & 1.50857 & 0.22773 & Accept \\
\hline & GDPP does not Granger Cause $\mathrm{CO}_{2}$ & \multirow{2}{*}{33} & \multirow{2}{*}{5} & 1.99719 & 0.11887 & Accept \\
\hline & $\mathrm{CO}_{2}$ does not Granger Cause GDPP & & & 1.08321 & 0.39693 & Accept \\
\hline \multirow{4}{*}{ Netherlands } & ECI does not Granger Cause $\mathrm{PCO}_{2}$ & 37 & 1 & 0.47594 & 0.49495 & Accept \\
\hline & $\mathrm{PCO}_{2}$ does not Granger Cause ECI & 31 & 1 & 3.02977 & 0.09079 & Reject \\
\hline & GDPP does not Granger Cause $\mathrm{CO}_{2}$ & 37 & 1 & 1.12933 & 0.29541 & Accept \\
\hline & $\mathrm{CO}_{2}$ does not Granger Cause GDPP & 31 & 1 & 0.29590 & 0.59001 & Accept \\
\hline & ECI does not Granger Cause $\mathrm{PCO}_{2}$ & & & 0.09839 & 0.75569 & Accept \\
\hline Greece & $\mathrm{PCO}_{2}$ does not Granger Cause ECI & 37 & 1 & 0.77782 & 0.38400 & Accept \\
\hline Ureece & GDPP does not Granger Cause $\mathrm{CO}_{2}$ & & & 0.00297 & 0.95684 & Accept \\
\hline & $\mathrm{CO}_{2}$ does not Granger Cause GDPP & 31 & 1 & 0.24599 & 0.62311 & Accept \\
\hline & ECI does not Granger Cause $\mathrm{PCO}_{2}$ & 37 & 1 & 4.89681 & 0.03372 & Reject \\
\hline Denmark & $\mathrm{PCO}_{2}$ does not Granger Cause ECI & 31 & 1 & 0.09204 & 0.76345 & Accept \\
\hline Denmark & GDPP does not Granger Cause $\mathrm{CO}_{2}$ & 37 & 1 & 6.99012 & 0.01231 & Reject \\
\hline & $\mathrm{CO}_{2}$ does not Granger Cause GDPP & 31 & 1 & 0.03004 & 0.86342 & Accept \\
\hline
\end{tabular}


Based on the long-run causality tests among $\mathrm{PCO}_{2}$, ECI and GDPP in the nine countries, we can establish an evaluation matrix to identify the differences of the possible impacts resulted from reducing $\mathrm{CO}_{2}$ emission to energy consumption and economic growth. Herein, we defined the risk as six levels: (1) Remote-Probability of less than 10\%; (2) Highly Unlikely-Probability between 10\% and 35\%; (3) Possible-Probability between $36 \%$ and 50\%; (4) Probable-Probability between 51\% and 75\%; (5) Highly Likely_Probability 76\% and 90\%; and (6) Certain-Probability above $90 \%$. The assessment result is shown in Table 3. The results show that the impact of reducing $\mathrm{CO}_{2}$ emissions on economic growth for different countries varies. In general, reducing $\mathrm{CO}_{2}$ emission has more negative impacts on the economic growth of Italy, followed by Portugal, and has the lowest impacts on the United Kingdom and Sweden.

Table 3. Risk assessment based on the causality analysis.

\begin{tabular}{|c|c|c|c|c|c|c|}
\hline Causality & $\begin{array}{l}\text { Remote } \\
(<\mathbf{1 0} \%) \\
\end{array}$ & $\begin{array}{c}\text { Highly Unlikely } \\
(10 \%-35 \%)\end{array}$ & $\begin{array}{c}\text { Possible } \\
(36 \%-50 \%)\end{array}$ & $\begin{array}{c}\text { Probable } \\
(51 \%-75 \%)\end{array}$ & $\begin{array}{c}\text { Highly Likely } \\
(76 \%-90 \%)\end{array}$ & $\begin{array}{l}\text { Certain } \\
(>90 \%) \\
\end{array}$ \\
\hline $\begin{array}{l}\mathrm{PCO}_{2} \text { does } \\
\text { not Granger } \\
\text { Cause ECI } \\
\end{array}$ & $\begin{array}{l}\text { France; Spain; } \\
\text { Sweden; } \\
\text { Denmark }\end{array}$ & $\begin{array}{l}\text { United Kingdom; } \\
\text { Portugal; }\end{array}$ & $\begin{array}{l}\text { Italy; } \\
\text { Netherlands }\end{array}$ & & Greece & \\
\hline $\begin{array}{l}\text { ECI does not } \\
\text { Granger } \\
\text { Cause } \mathrm{PCO}_{2}\end{array}$ & $\begin{array}{l}\text { France; Spain; } \\
\text { Sweden; } \\
\text { Netherlands }\end{array}$ & $\begin{array}{l}\text { Italy; } \\
\text { Portugal; }\end{array}$ & Greece & Denmark & & $\begin{array}{l}\text { United } \\
\text { Kingdom }\end{array}$ \\
\hline $\begin{array}{l}\text { GDPP does } \\
\text { not Granger } \\
\text { Cause } \mathrm{PCO}_{2}\end{array}$ & Denmark & $\begin{array}{l}\text { United Kingdom; } \\
\text { Sweden; } \\
\text { Portugal; } \\
\text { Netherlands }\end{array}$ & France & Italy & & $\begin{array}{l}\text { Spain; } \\
\text { Greece }\end{array}$ \\
\hline $\begin{array}{l}\mathrm{PCO}_{2} \text { does } \\
\text { not Granger } \\
\text { Cause GDPP }\end{array}$ & & Italy & Portugal & $\begin{array}{l}\text { France; } \\
\text { Netherlands; } \\
\text { Greece }\end{array}$ & $\begin{array}{l}\text { Spain; } \\
\text { Denmark }\end{array}$ & $\begin{array}{l}\text { United } \\
\text { Kingdom; } \\
\text { Sweden }\end{array}$ \\
\hline
\end{tabular}

\section{Conclusions}

Issues on climate change have been recognized as a serious challenge for addressing regional sustainable development at both a global and local level. This paper examined the relationship among $\mathrm{CO}_{2}$ emission, fossil energy consumption, and economic growth in period 1970-2008 of nine European countries, by employing the Granger Causality Test, followed by the impacts analysis of carbon reduction to local economic growth. The results show that there are both unidirectional and dual-directional Granger causality existing in the nine countries. However, given the background of the environmental industries' development in European countries, reducing carbon emissions would have short-term throes to economic development, because, in the long-term scenario, the reduction of carbon emission also could accelerate the development of renewable energies, such as in Germany [28].

\section{Acknowledgments}

This research is supported by National Natural Science Foundation of China (41101126, 71033004, 71303230), the International Cooperation Project "Urban Co-benefits Research", 100 Talents Program 
of the Chinese Academy of Sciences (2008-318), Ministry of Science and Technology of China (2011BAJ06B01), and the Alexander von Humboldt Foundation. Special thanks go to the anonymous reviewers for their valuable comments.

\section{Supplementary Materials}

Supplementary materials can be accessed at: http:/www.mdpi.com/2071-1050/6/2/1037/s1.

\section{Author Contributions}

Bing Xue conducted the research, contributed to data analysis and paper-wrote; Yong Geng, Katrin Müller, Chengpeng Lu and Wanxia Ren contributed to data analysis and revision.

\section{Conflicts of Interest}

The authors declare no conflict of interest.

\section{References}

1. Allen, M.R.; Frame, D.J.; Huntingford, C.; Jones, C.D.; Lowe, J.A.; Meinshausen, M.; Meinshausen, N. Warming caused by cumulative carbon emissions towards the trillionth tonne. Nature 2009, 458, 1163-1166.

2. Matthews, H.D.; Gillett, N.P.; Stott, P.A.; Zickfeld, K. The proportionality of global warming to cumulative carbon emissions. Nature 2009, 459, 829-832.

3. Meinshausen, M.; Meinshausen, N.; Hare, W.; Raper, S.C.B.; Frieler, K.; Knutti, R.; Frame, D.J.; Allen, M.R. Greenhouse-gas emission targets for limiting global warming to 2 degree. Nature 2009, 458, 1158-1162.

4. Qin, D. Recent progress on climatic change science. Adv. Clim. Change Res. 2007, 3, 63-73.

5. Intergovernmental Panel on Climate Change (IPCC). Contribution of Working Group I to the Fourth Assessment Report of the Intergovernmental Panel on Climate Change; Cambridge University Press: New York, NY, USA, 2007.

6. Aunan, K.; Fang, J.; Hu, T.; Seip, H.M.; Vennemo, H. Climate change and air quality: Measures with co-benefits in China. Environ. Sci. Technol. 2006, 40, 4822-4829.

7. Xue, B.; Li, C.; Liu, Z.; Geng, Y.; Xi, F. Analysis on $\mathrm{CO}_{2}$ emission and urbanization at global level during 1970-2007. Adv. Clim. Change Res. 2011, 7, 423-427.

8. Van Renssen, S. Climate policy confronts competitiveness. Nat. Clim. Change 2014, 4, 8-9.

9. Wang, D.; Sun, G. Relationships between carbon emissions and economic growth, foreign direct investment and export in China. Appl. Mech. Mater. 2014, 448, 4544-4547.

10. Yue, T.; Long, R.; Chen, H.; Zhao, X. The optimal $\mathrm{CO}_{2}$ emissions reduction path in Jiangsu province: An expanded IPAT approach. Appl. Energy 2013, 112, 1510-1517.

11. Hope, C.; Hope, M. The social cost of $\mathrm{CO}_{2}$ in a low-growth world. Nat. Clim. Change 2013, 3, $722-724$.

12. Lu, W.; Chen, C.; Su, M.; Chen, B.; Cai, Y.; Xing, T. Urban energy consumption and related carbon emission estimation: A study at the sector scale. Front. Earth Sci. 2013, 7, 480-486. 
13. Belke, A.; Dreger, C.; de Haan, F. Energy consumption and economic growth: New insights into the co-integration relationship. Available online: http://www.rwi-essen.de/media/content/pages/ publikationen/ruhr-economic-papers/REP_10_190.pdf (accessed on 30 January 2014).

14. Firouz, F. Causal relationship between energy consumption and GDP: A Markov-switching (MS) causality. Energy 2011, 36, 4165-4170.

15. Engle, R.F.; Granger, C. Cointegration and error correction: Representation, estimation and testing. Econometrica 1987, 55, 251-276.

16. Liu, Z.; Guan, D.; Crawford-Brown, D.; Zhang, Q.; He, K. Energy policy: A low-carbon road map for China. Nature 2013, 500, 143-145.

17. Geng, Y. Eco-indicators: Improve China's sustainability targets. Nature 2011, 477, doi:10.1038/477162b.

18. Chen, Y.; Timilsina, H.; Landis, F. Economic implications of reducing carbon emissions from energy use and industrial processes in Brazil. J. Environ. Manag. 2013, 130, 436-446.

19. Zhang, Y.; Zhao, T. Analysis on emission reduction targets of carbon dioxide in China. Adv. Mater. Res. 2013, 734, 1891-1895.

20. Zhang, M.; Wang, W. Decouple indicators on the $\mathrm{CO}_{2}$ emission-economic growth linkage: The Jiangsu Province case. Ecol. Indicat. 2013, 32, 239-244.

21. Ma, Z.; Xue, B.; Geng, Y.; Ren, W.; Fujita, T.; Zhang, Z.; de Oliveira, J.P.; Jacques, D.A.; Xi, F. Co-benefits analysis on climate change and environmental effects of wind-power: A case study from Xinjiang, China. Renew. Energy 2013, 57, 35-42.

22. Ang, J.B. Economic development, pollutant emissions and energy consumption in Malaysia. J. Policy Model. 2008, 30, 271-278.

23. Shahbaz, M.; Kumar Tiwari, A.; Nasir, M. The effects of financial development, economic growth, coal consumption and trade openness on $\mathrm{CO}_{2}$ emissions in South Africa. Energy Policy 2013, 61, 1452-1459.

24. Menyah, K.; Wolde-Rufael, Y. Energy consumption, pollutant emissions and economic growth in South Africa. Energy Econ. 2010, 32, 1374-1382.

25. Ang, J.B. $\mathrm{CO}_{2}$ emissions, energy consumption, and output in France. Energy Policy 2007, 35, 4772-4778.

26. Marrero, G.A. Greenhouse gases emissions, growth and the energy mix in Europe. Energy Econ. 2010, 32, 1356-1363.

27. Marrero, G.A.; Ramos-Real, F.J. Activity sectors and energy intensity: Decomposition analysis and policy implications for European countries (1991-2005). Energies 2013, 6, 2521-2540.

28. Kirsten, S. Renewable Energy Sources Act and Trading of Emission Certificates: A national and a supranational tool direct energy turnover to renewable electricity-supply in Germany. Energy Policy 2014, 64, 302-312.

(C) 2014 by the authors; licensee MDPI, Basel, Switzerland. This article is an open access article distributed under the terms and conditions of the Creative Commons Attribution license (http://creativecommons.org/licenses/by/3.0/). 